\title{
RESPON HARGA PRODUSEN TERHADAP PERUBAHAN HARGA KONSUMEN BAWANG MERAH DI INDONESIA
}

\author{
Illia Seldon Magfiroh ${ }^{1}$, Rena Yunita Rahman ${ }^{1}$, Intan Kartika Setyawati', dan Ahmad Zainud- \\ $\operatorname{din}^{1}$ \\ ${ }^{1}$ Dosen, Program Studi Agribisnis Fakultas Pertanian Universitas Jember \\ email: illia.faperta@unej.ac.id
}

\begin{abstract}
High price fluctuations in onions can cause prices at the consumer level to change in a relatively quick time. However, the price change is not necessarily enjoyed by most of the onion farmers. This implies a high marketing margin and low farmer prices. This study aims to analyze the integration of onion consumer market with onion producer market in Indonesia by using VECM (Vector Error Correction Model). Monthly onion price data with 48 time series period is used to analyze the onion market integration. The results show that only the consumer market that affects the market of onion producers (one way). There are short-term and long-term market integration between the consumer market and the onion producers. However, changes that occur in the consumer market are not always accepted by the onion producers of the same scale. This shows that the price information of onion in the producer's market is not always transmitted perfectly to the onion producer market.
\end{abstract}

Keywords: market integration, onion, price change, VECM

\section{PENDAHULUAN}

Bawang merah merupakan salah satu komoditas pertanian penting dan strategis di Indonesia. Terdapat beberapa alasan yang membuat bawang merah memiliki peran penting dan strategis yaitu (1) pengembangan komoditas bawang merah sebagai bagian dari subsektor hortikultura berpotensi menjadi sumber pertumbuhan baru bagi peningkatan PDB sektor pertanian; (2) pengembangan produksi komoditas bawang merah mendukung upaya peningkatan ketahanan pangan dan ketersediaan pangan; (3) perubahan harga bawang merah yang relatif cepat (berfluktuasi) dapat menyebabkan inflasi bagi perekonomian Indonesia.

Potensi bawang merah sangat bagus karena tanaman ini dapat dibudidayakan hampir di seluruh Indonesia, namun masalah yang sering dihadapi oleh bawang merah adalah fluktuasi harga yang tidak menentu. Pada waktu tertentu seperti hari raya lebaran dan hari-hari besar, harga bawang merah terkadang menjadi sangat tinggi. Kondisi tersebut harus diimbangi dengan peningkatan penawaran agar tidak terjadi inflasi. Permasalahan fluktuasi harga ini dikarenakan produksi bawang merah yang bersifat musiman dan sebagai salah satu sayuran yang mudah rusak. Pada tahun 2013, bawang merah menempati urutan pertama dalam kontribusinya terhadap inflasi dari kelompok bahan makanan yaitu sebesar $0.38 \%$ (TPI 2013). Oleh karena itu, aspek harga menjadi permasalahan penting pengembangan bawang merah di Indonesia.

Perkembangan harga konsumen bawang merah di Indonesia selama periode 2012-2015 menunjukkan kecenderungan meningkat namun harga di tingkat produsen relatif stabil. Hal ini menyebabkan adanya margin pemasaran bawang merah antara produsen dan konsumen semakin besar. Margin harga menunjukkan besarnya disparitas harga yang terjadi. Peningkatan harga bawang merah di tingkat konsumen yang lebih tinggi dibandingkan dengan peningkatan harga di tingkat produsen menyebabkan margin harga bawang merah semakin lebar terutama pada bulan Juni-Agustus (Tabel 1).

Fluktuasi harga yang tinggi pada bawang merah dapat menyebabkan harga di tingkat konsumen dapat berubah dalam waktu relatif cepat. Perubahan harga tersebut diharapkan akan direspon secara cepat pula oleh lembaga pemasaran sehingga dapat segera mengambil keputusan yang tepat dan pasar menjadi lebih efisien (Asmara, 2010). Faktanya, perubahan harga tersebut belum tentu dinikmati oleh sebagian besar petani bawang merah. Namun, fluktuasi harga tersebut 
Tabel 1. Perkembangan harga produsen dan harga konsumen bawang merah, $2012-2015$

\begin{tabular}{|c|c|c|c|c|c|c|c|c|c|c|c|c|c|}
\hline \multirow{2}{*}{$\begin{array}{l}\text { Ta- } \\
\text { hun }\end{array}$} & \multicolumn{12}{|c|}{ Bulan } & \multirow{2}{*}{$\begin{array}{l}\text { Growth } \\
\text { average }\end{array}$} \\
\hline & Jan & Feb & Mar & Apr & Mei & Jun & Jul & Ags & Sep & Okt & Nov & Des & \\
\hline & \multicolumn{13}{|c|}{ Harga Produsen $(\mathrm{Rp} / \mathrm{kg})$} \\
\hline 2012 & 12,463 & 12,393 & 12,268 & 12,471 & 12,802 & 13,167 & 13,159 & 13,013 & 12,771 & 12,745 & 12,980 & 13,565 & 0.79 \\
\hline 2013 & 14,264 & 14,583 & 15,023 & 15,185 & 14,653 & 14,358 & 14,959 & 15,610 & 15,023 & 14,720 & 14,699 & 14,749 & 0.34 \\
\hline 2014 & 15,638 & 15,460 & 15,428 & 15,499 & 15,528 & 15,771 & 16,129 & 15,909 & 15,498 & 15,478 & 15,294 & 15,465 & -0.09 \\
\hline \multirow[t]{2}{*}{2015} & & 15,775 & & & & & & & & & & & 0.04 \\
\hline & \multicolumn{13}{|c|}{ Harga Konsumen $(\mathrm{Rp} / \mathrm{kg})$} \\
\hline 2012 & 21,103 & 20,696 & 20,649 & 21,358 & 22,546 & 23,521 & 23,020 & 22,081 & 21,681 & 21,138 & 22,001 & 23,588 & 1.08 \\
\hline 2013 & 23,742 & 25,575 & 29,740 & 31,720 & 28,933 & 27,180 & 32,519 & 36,582 & 34,834 & 32,163 & 32,241 & 33,783 & 3.69 \\
\hline 2014 & 31,182 & 28,738 & 27,401 & 26,407 & 26,260 & 27,123 & 28,440 & 27,226 & 24,843 & 24,052 & 23,213 & 23,247 & -2.55 \\
\hline \multirow[t]{2}{*}{2015} & 23,307 & 22,727 & 23,773 & 26,091 & 26,986 & 28,626 & 26,736 & 24,062 & 22,424 & 22,972 & 22,958 & 25,238 & 0.93 \\
\hline & \multicolumn{13}{|c|}{ Margin harga produsen dan konsumen $(\mathrm{Rp} / \mathrm{kg})$} \\
\hline 2012 & 8,640 & & & & 9,745 & 10,354 & 9,861 & 9,068 & 8,910 & 8,393 & 9,021 & 10,023 & 1.57 \\
\hline 2013 & 9,478 & 10,992 & 14,717 & 16,535 & 14,280 & 12,822 & 17,560 & 20,972 & 19,811 & 17,443 & 17,542 & 19,034 & 7.85 \\
\hline 2014 & 15,544 & 13,278 & 11,973 & 10,908 & 10,732 & 11,352 & 12,311 & 11,317 & 9,345 & 8,574 & 7,919 & 7,782 & -5.8 \\
\hline 2015 & 7,277 & 6,952 & 7,823 & 9,592 & 10,318 & 11,535 & 10,303 & 8,478 & 7,170 & 7,540 & 7,409 & 9,199 & 3.07 \\
\hline
\end{tabular}

Sumber: Pusat Data dan Informasi Kementerian Pertanian, 2016

sering dimanfaatkan para pedagang untuk mempermainkan informasi harga di tingkat produsen. Hal tersebut menyebabkan terjadinya asimetri informasi harga dari pasar konsumen ke pasar produsen yang berarti kenaikan hargadi tingkat konsumen belum tentu diikuti dengan peningkatan harga di tingkat produsen, begitu pula sebaliknya (Simatupang, 1999). Implikasinya adalah marjin pemasaran yang semakin tinggi dan harga yang diterima petani yang rendah. Irawan (2007) mengemukakan bahwa kondisi tersebut terjadi adanya fluktuasi harga akan membuka peluang terjadinya permainan harga di tingkat petani oleh pedagang dengan alasan adanya perubahan harga di tingkat konsumen.

Ketersediaan informasi pasar utamanya harga sangat diperlukan untuk mencegah terjadinya asimetri informasi pasar, sehingga perubahan harga dapat segera direspon oleh para pelaku pasar dan pengambilan keputusan dapat dilakukan secara cepat dan tepat (FAO, et al, 2011). Hal tersebut menunjukkan bahwa antara pasar yang satu dengan pasar yang lainnya telah terintegrasi dengan baik. Hal tersebut sesuai dengan Ravalion (1986) yang menyatakan bahwa dalam suatu pasar yang terintegrasi maka harga dari pasar yang berbeda mempunyai hubungan yang positif sebagai pencerminan lancarnya arus informasi pasar. Pasar yang terintegrasi akan tercapai jika terdapat informasi pasar yang sama, memadai, disalurkan dengan cepat ke pasar lain dan memiliki hubungan yang positif antara harganya di pasar yang berbeda (Asmarantaka, 2009; Baffes dan Bruce, 2003).

Informasi harga yang terintegrasi dari konsumen bawang merah ke produsen/petani bawang merah akan berimplikasi terhadap efisiensi pemasaran bawang merah. Hal ini dikarenakan perubahan harga bawang merah di tingkat konsumen akan diikuti oleh perubahan harga di tingkat produsen/petani bawang merah sehingga tidak merugikan para pelaku pemasaran baik produsen maupun lembaga pemasaran. Namun fakta dilapangan menunjukkan bawah besarnya perubahan harga bawang merah di tingkat konsumen tidak selalu diikuti oleh perubahan harga di tingkat produsen dengan besaran yang sama (Gambar 1).

Kajian integrasi pasar maupun respon harga bawang merah sudah pernah dilakukan. Asmara dan Ardhiani (2010) menunjukan bahwa struktur pasar bawang merah cenderung mengarah pada persaingan oligopsoni. Analisis integrasi pasar vertikal menunjukkan bahwa pasar terintegrasi secara lemah baik dalam jangka panjang maupun dalam jangka pendek. Informasi pasar umumnya tidak ditransmisikan secara sempurna oleh para pelaku pasar, khususnya pedagang besar yang bertindak sebagai pihak pembuat harga (price maker). 
Selanjutnya, Dhewi (2008) menjelaskan bahwa struktur pasar bawang merah yang terjadi adalah struktur pasar oligopsoni. Pembentukan harga di tingkat petani dan pengecer terintegrasi cukup lemah, yang berarti keeratan hubungan antara keduanya cukup lemah. Sedangkan Penelitian Ruslan (2016) menjelaskan bahwa pemasaran bawang merah terjadi dengan tidak efisien antara daerah sentra produsen dan konsumen di Indonesia. Pemasaran yang tidak efisien tersebut dapat dilihat dari transmisi harga antar lembaga pemasaran bawang merah yang bersifat asimetris di mana pada hubugan produsen-grosir terjadi asimetris harga dalam jangka pendek sedangkan grosir-pengecer terjadi asimetris dalam jangka panjang.

Penelitian ini merupakan pengembangan dari penelitian tentang integrasi pasar bawang merah. Penelitian ini mencoba melihat respon produsen(petani) terhadap perubahan harga yang terjadi di pasar konsumen baik dalam jangka pendek dan jangka panjang. Perbedaan lainnya adalah pada penelitian ini juga menganalisis fluktuasi harga yang terjadi di pasar produsen dan konsumen bawang merah sehingga akan terlihat hubungan antara pasar konsumen dan produsen.

Berdasarkan latar belakang di atas, tulisan ini akan menekankan pada bagaimana respon perubahan harga produsen terhadap perubahan harga konsumen bawang merah di Indonesia. Oleh sebab itu, menjadi penting untuk menganalisis respon harga di tingkat petani terhadap perubahan harga konsumen di Indonesia. Penelitian ini bertujuan untuk menganalisis integrasi pasar konsumen bawang merah dengan pasar produsen bawang merah di Indonesia.

\section{METODE PENELITIAN}

Penelitian respon harga produsen terhadap perubahan harga konsumen menggunakan data sekunder. Data yang digunakan untuk menganalisis mengenai integrasi pasar di tingkat produsen dan konsumen berupa data sekunder dalam bentuk data deret waktu (time series) bulanan dengan periode waktu 48 series yaitu dari Bulan Januari tahun 2012 hingga Bulan Desember tahun 2015. Penentuan rentang waktu pada data yang digunakan beradasarkan pertimbangan bahwa pada tahun tersebut terjadi fluktuasi harga yang relatif tinggi dibandingkan tahun sebelumnya. Jenis data bulanan yang dikumpulkan berupa harga bawang merah di tingkat produsen, dan harga bawang merah di tingkat konsumen.

Pengolahan data untuk menjawab tujuan penelitian digunakan perangkat lunak excel 2007 dan Eviews 7.0. Hasil pengolahan data disajikan dalam bentuk tabulasi dan grafik. Model VAR (Vector Autoregressive)/VECM (Vector Error Correction Model) digunakan untuk menganalisis ada tidaknya integrasi pasar produsen dan konsumen bawang merah. Model VAR/VECM adalah suatu sistem persamaan yang memperlihatkan setiap variabel sebagai fungsi linier dari konstanta dan nilai lag (lampau) dari variabel itu sendiri serta nilai lag dari variabel lain yang ada di dalam sistem. Sehingga, variabel penjelas dalam Model VAR/VECM meliputi nilai lag dari seluruh variabel tak bebas dalam sistem. Adapun model VAR dari integrasi pasar produsen dan konsumen bawang merah adalah sebagai berikut:

$$
\begin{gathered}
\text { Pkons }_{t}=\alpha_{1}+\delta_{1} t+\phi_{11} \text { Pkons }_{t-1}+\ldots+\phi_{l p} \\
\text { Pkons }_{t-p}+\beta_{1 I} \text { Pprod }_{t-1}+\ldots+\beta_{1 q} \text { Pprod }_{t-q}+\varepsilon_{t}(1) \\
\text { dan } \\
\text { Pprod }_{t}=\alpha_{2}+\delta_{2} t+\phi_{2 l} \text { Pprod }_{t-1}+\ldots+\phi_{2 p} \\
\text { Pprod }_{t-p}+\beta_{2 I} \text { Pkons }_{t-1}+\ldots+\beta_{l q} \text { Pkons }_{t-q}+\varepsilon_{t}(2)
\end{gathered}
$$

dimana Pkons, adalah vektor $n \times 1$ dari harga bawang merah di tingkat konsumen pada orde satu, umumnya dinotasikan I(1); Pprod $_{t}$ merupakan harga bawang merah di tingkat produsen dan et adalah $n \times 1$ vektor inovasi (Rosadi, 2012). Pada penelitian ini $n$ yang diteliti berjumlah 2 variabel harga (masing-masing harga bawang merah ditingkat konsumen dan di tingkat produsen). Apabila variabel-variabel tersebut ditransformasi dalam bentuk vektor terlihat pada formulasi di bawah ini:

$$
\begin{gathered}
{\left[\begin{array}{l}
\text { Pprod } \\
\text { PNonst }
\end{array}\right]=\left[\begin{array}{l}
\alpha_{1} \\
\alpha_{2}
\end{array}\right]+\left[\begin{array}{ll}
\alpha_{11} & \alpha_{12} \\
\alpha_{21} & \alpha_{22}
\end{array}\right]\left[\begin{array}{l}
\text { PNonst } \\
\text { PProd } \\
\text { PPr-1 }
\end{array}\right]} \\
+\left[\begin{array}{l}
\varepsilon_{1 t} \\
\varepsilon_{2 t}
\end{array}\right]
\end{gathered}
$$

dimana:

Pprod = harga bawang merah di tingkat produsen $(\mathrm{Rp} / \mathrm{kg})$

Pkons = harga bawang merah di tingkat konsumen $(\mathrm{Rp} / \mathrm{kg})$

$\alpha_{\mathrm{i}} \quad=$ parameter yang akan diestimasi

Adapun spesifikasi model VECM integrasi pasar bawang merah ditingkat produsen dan konsumen adalah sebagai berikut : 


$$
\begin{aligned}
& \Delta \text { Pkons }_{\mathrm{t}}=\varphi_{1}+\delta_{1} \mathrm{t}+\lambda_{1} \mathrm{e}_{\mathrm{t}-1}+\gamma_{11} \Delta \text { Pkons }_{\mathrm{t}-1}+\ldots+\gamma \\
& { }_{1 \mathrm{p}} \Delta \text { Pkons }_{\mathrm{t}-\mathrm{p}}+\omega_{11} \Delta \text { Pprod }_{\mathrm{t}-1}+\ldots+\omega_{1 \mathrm{q}} \Delta \text { Pprod }_{\mathrm{t}-\mathrm{q}}+\varepsilon_{1 \mathrm{t}}
\end{aligned}
$$

\begin{tabular}{|c|c|}
\hline Pkons $_{t}$ & $\begin{array}{l}=\text { harga bawang merah di ting- } \\
\text { kat konsumen }(\mathrm{Rp} / \mathrm{kg})\end{array}$ \\
\hline$\varphi_{\mathrm{x}}$ & $=$ vektor intercept \\
\hline$\nu_{2 p ;} \omega_{2 q}$ & $=$ vektor koefisien regresi \\
\hline $\mathrm{t}^{-2}$ & $=$ time trend \\
\hline$V_{2 p}$ & $=\alpha \times \beta^{\prime}$ dimana b' mengandung \\
\hline & $\begin{array}{ll}\text { persamaan } & \text { kointegrasi } \\
\text { jangka panjang } & \end{array}$ \\
\hline Pkond $_{t-1} ;$ Pprod $_{t-1}$ & $=$ variabel in-level \\
\hline & $\begin{array}{l}=\text { matriks koefisien regresi } \\
\text { yang menunjukkan adanya } \\
\text { integrasi jangka pendek }\end{array}$ \\
\hline$\varepsilon \_t$ & ror term \\
\hline
\end{tabular}

\section{HASIL DAN PEMBAHASAN}

Harga bawang merah di pasar konsumen secara teoritis normatif akan saling mempengaruhi perubahan harga bawang merah di tingkat produsen, jika harga bawang merah ditingkat konsumen mengalami peningkatan, harga di tingkat produsen juga akan mengalami peningkatan begitu pula sebaliknya. Hal tersebut akan terjadi jika kedua pasar tersebut terintegrasi dimanaakan terjadi transmisi harga dari pasar konsumen ke produsen dan sebaliknya. Namun faktanya, harga bawang merah di tingkat konsumen memiliki tingkat fluktuasi yang tinggi namun harga di tingkat produsen relatif stabil. Hal ini menunjukkan bahwa peningkatan harga bawang merah di tingkat konsumen tidak ditransmisikan ke tingkat produsen secara sempurna. Sehingga jika terjadi peningkatan harga di tingkat konsumen, produsen belum tentu menikmati peningkatan harga tersebut. Hal ini dapat dilihat pada Gambar 2 berikut.

Gambar 2 menunjukkan bahwa harga di tingkat produsen dengan harga di tingkat konsumen memiliki kecenderungan yang sama, namun harga di tingkat konsumen memiliki fluktuasi yang tinggi sedangkan harga di tingkat produsen relatif setabil.

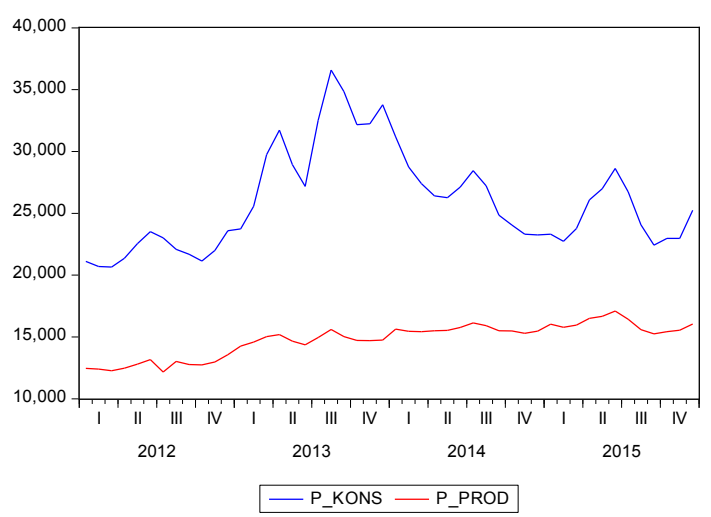

Gambar 2. Pergerakan Harga Bawang Merah di Tingkat Produsen dan Konsumen

Fluktuasi harga bawang merah di tingkat konsumen menyebabkan margin pemasaran yang dihasilkan juga relatif sangat tinggi. Hal ini menunjukkan bahwa peningkatan harga di tingkat konsumen tidak serta merta diteruskan atau ditransmisikan secara cepat kepada produsen bawang merah. Hal ini berdampak pada keuntungan petani yang relatif tetap meskipun harga bawang merah di tingkat konsumen cenderung tinggi. Margin yang tinggi tersebut dinikmati oleh pedagang yang sering memanfaatkan perubahan harga yang terjadi di pasar konsumen. Hal ini sesuai dengan penelitian Simatupang (1999) yang menyatakan bahwa fluktuasi harga yang tinggi akan memberi peluang kepada pedagang untuk memanipulasi informasi harga di tingkat petani sehingga transmisi harga dari pasar konsumen kepada petani cenderung bersifat asimetris dalam pengertian jika terjadi kenaikan harga di tingkat konsumen maka kenaikan harga tersebut tidak diteruskan kepada petani secara cepat dan sempurna, sebaliknya jika terjadi penurunan harga.

1) Uji Stationer

Berdasarkan Tabel 2 dapat dijelaskan bahwa variabel harga bawang merah ditingkat produsen maupun konsumen telah dilakukan analisis stationeritas pada taraf kesalahan sebesar $1 \%$, 5\%, dan $10 \%$ dengan menggunakan kriteria dengan intersep tanpa tren. Hasil analisis menunjukkan bahwa harga bawang merah di tingkat produsen dan konsumen tidak stationer pada level (stationer pada first difference). Hal ini ditunjukkan oleh nilai ADF statistik pada level yang lebih besar dibandingkan dengan nilai kritis McKinnon,sedangkan nilai ADF pada first difference menunjukkan nilai yang lebih kecil daripada nilai McKinnon sehingga dikatakan stationer pada first difference. 
Tabel 2. Hasil Uji Root pada Variabel Harga Bawang Merah di Tingkat Produsen dan Konsumen

\begin{tabular}{|c|c|c|c|c|c|c|}
\hline \multirow[b]{2}{*}{ Variabel } & \multirow[b]{2}{*}{ Differenced } & \multicolumn{4}{|c|}{ Intersep tanpa tren } & \multirow[b]{2}{*}{ Kesimpulan } \\
\hline & & $\begin{array}{l}\text { Nilai ADF test } \\
\text { statistic }\end{array}$ & $1 \%$ & $5 \%$ & $10 \%$ & \\
\hline \multirow[t]{2}{*}{ P_Prod } & $\mathrm{I}(0)$ & -1.619138 & -3.577723 & -2.925169 & -2.600658 & Tidak Stationer \\
\hline & $\mathrm{I}(1)$ & -6.349093 & -3.581152 & -2.926622 & -2.601424 & Stationer \\
\hline \multirow[t]{2}{*}{ P_Kons } & $\mathrm{I}(0)$ & -2.067229 & -3.588509 & -2.929734 & -2.603064 & Tidak Stationer \\
\hline & $\mathrm{I}(1)$ & -3.755884 & -3.588509 & -2.929734 & -2.603064 & Stationer \\
\hline
\end{tabular}

Sumber: Data diolah

Tabel 3. Kriteria Lag Optimum Harga Bawang Merah di Tingkat Konsumen dan Produsen

\begin{tabular}{|c|c|c|c|}
\hline Lag & AIC & SC & HQ \\
\hline 0 & 36.29327 & 36.37437 & 36.32334 \\
\hline 1 & 32.57429 & $32.81758^{*}$ & 32.66451 \\
\hline 2 & 32.54252 & 32.94801 & 32.69289 \\
\hline 3 & 32.42015 & 32.98785 & $32.63068^{*}$ \\
\hline 4 & $32.37096^{*}$ & 33.10086 & 32.64164 \\
\hline
\end{tabular}

\section{2) Penentuan lag Optimal}

Penentuan panjang lag atau selang optimal yang digunakan adalah berdasarkan kriteria AIC (Akaike Infromation Criteria). Panjang lag otimal dapat diketahui pada Tabel 3. Berdasarkan Tabel 3 dapat dijelaskan bahwa lag optimal yang dapat digunakan dalam model VAR/ VECM adalah lag 4. Hal ini berdasarkan nilai yang dihasilkan pada kriteria AIC (Akaike Infromation Criteria) yang menunjukkan hasil pada lag 4. Penentuan panjang lag digunakan untuk menghilangkan masalah autokorelasi dan heteroskedastisitas yang ada pada model VAR/ VECM yang akan digunakan (Enders, 1995).

\section{3) Analisis Kointegrasi}

Uji kointegrasi digunakan untuk melihat apakah variabel harga bawang merah di tingkat konsumen maupun produsen terintegrasi pada derajat yang sama sehingga dapat dikatakan terkointegrasi. Hasil uji kointegrasi dapat dilihat pada Tabel 4.

Tabel 4 mengindikasikan bahwa terdapat hubungan kointegrasi (integrasi jangka panjang) antara pasar konsumen bwang merah dengan pasar produsen bawang merah. Indikasi tersebut ditunjukkan oleh nilai trace statistic maupun maximum eigenvalue yang menolak $\mathrm{H} 0$ sampai pada tingkat signifikansi 5\% adalah pada rank 1, hal ini berarti terdapat satu persamaan yang terkointegrasi atau terdapat satu persamaan yang dapat menjelaskan adanya hubungan kointegrasi pada variabel-variabel dalam model (harga konsumen dan produsen bawang merah).

\section{4) Uji Kausalitas Garanger}

Uji kausalitas Granger dilakukan untuk melihat hubungan kausalitas di antara variabel-variabel yang ada dalam model. Pengujian hubungan sebab akibat, dalam pengertian Granger (1969), digunakan untuk melihat hubungan antar pasar bawang merah di tingkat produsen dan konsumen. Apabila pengujian dengan menggunakan metode Granger test menunjukkan bahwa hubungan kausalitas terjadi dua arah menunjukkan pasar terlah terintegrasi. Hasil uji kausalitas Granger dapat dilihat pada Tabel 5.

Berdasarkan nilai probabilitas yang dihasilkan pada uji kausalitas Granger pada Tabel 5 menunjukkan bahwa hanya hipotesis harga konsumen bawang merah yang tidak menyebabkan harga produsen bawang merah yang ditolak. Hal ini dikarenakan nilai probablitas yang dihasilkan kurang dari taraf kesalahan 5\%, sehingga dapat disimpulkan bahwa harga bawang merah di tingkat konsumen mempengaruhi perubahan harga di tingkat produsen. Sedangkan harga bawang merah di tingkat produsen tidak mempengaruhi harga di tingkat konsumen.

Hal ini menunjukkan bahwa pasar konsumen bertindak sebagai pasar acuan sedangkan pasar produsen bertindak sebagai pasar pengikut. Hasil tersebut berkebalikan dari Penelitian Ruslan (2016) yang menunjukkan bahwa harga produsen bawang merah mempengaruhi harga grosir (PIKJ) sebaliknya harga grosir tidak mempengaruhi harga produsen bawang merah (Kab. Brebes), namun penelitian ini sejalan dengan 
Tabel 4. Hasil Pengujian Kointegrasi Johansen

\begin{tabular}{|c|l|c|c|c|c|}
\hline \multicolumn{2}{|c|}{ Hipotesis } & \multirow{2}{*}{ Trace Statistic } & Nilai kritis 5\% & Mx-Eigen Statistic & \multirow{2}{*}{ Nilai kritis 5\% } \\
\cline { 1 - 2 } $\mathrm{H}_{0}$ & $\mathrm{H}_{1}$ & & & & \\
\cline { 1 - 2 } $\mathrm{r}=0$ & $\mathrm{r}=1$ & 15.49471 & 7.930193 & 3.862485 & 14.26460 \\
\hline $\mathrm{r}=1$ & $\mathrm{r}=2$ & 3.067708 & 3.841466 & 3.067708 & 3.841466 \\
\hline
\end{tabular}

Tabel 5. Hasil Pengujian Kausalitas Granger

\begin{tabular}{|l|c|c|c|}
\hline Null Hypothesis: & Obs & F-Statistic & Probability \\
\hline P_Prod does not Granger Cause P_Kons & 45 & 0.16216 & 0.9212 \\
\hline P_Kons does not Granger Cause P_Prod & & 3.62125 & 0.0215 \\
\hline
\end{tabular}

penelitian Nuraeni et al (2015) yang menunjukkan bahwa terdapat kausalitas satu arah yaitu harga di tingkat produsen bawang merah dipengaruhi harga di tingkat grosir. Hal ini dikarenakan harga yang terbentuk di pasar lebih dominan ditentukan oleh perubahan harga di tingkat konsumen (dapat dilihat pada Tabel 2 dimana harga produsen relatif stabil sedangkan harga konsumen sangat berfluktuasi). Dengan demikian, menunjukkan pembentukan harga antar pasar bawang merah di Indonesia lebih dipengaruhi oleh sisi permintaan atau bersifat satu arah (dari pasar konsumen ke pasar produsen).

\section{Hasil Estimasi Vector Error Correction Mod- el}

Berdasarkan hasil analisis kausalitas Granger diperoleh hasil bahwa harga bawang merah di tingkat produsen dipengaruhi oleh harga bawang di tingkat konsumen. Selain itu, hasil uji kointegrasi menunjukkan bahwa harga konsumen bawang merah terintegrasi dalam jangka panjang dengan harga produsen bawang merah.

Hasil estimasi model VECM pada Tabel 6 diketahui bahwa hanya terdapat satu persamaan yang terkointegrasi dalam jangka panjang pada pasar konsumen bawang merah dan pasar produsen bawang merah. Hasil ini juga sesuai dengan hasil uji kausalitas granger yang menunjukkan hanya pasar konsumen yang mempengaruhi pasar produsen bawang merah (satu arah). Hal ini terjadi karena produsen bawang merah hanya bertindak sebagai price taker yang hanya tidak memiliki kemampuan mempengaruhi harga. Dengan demikian, pasar konsumen merupakan pasar acuan yang menentukan perubahan harga di pasar pengikut (pasar produsen bawang merah).
Hal ini merujuk pada hasil estimasi VECM yang menunjukkan bahwa dalam jangka panjang, pergerakan harga produsen bawang merah dipengaruhi oleh pergerakan harga di pasar konsumen bawang merah secara signifikan pada taraf kesalahan $1 \%$. Harga konsumen memiliki pengaruh positif terhadap perubahan harga produsen bawang merah sebesar 0,4498844. Tanda tersebut sesuai dengan pernyataan Ravalion (1986) yang menyatakan bahwa dalam suatu pasar yang terintegrasi maka harga dari pasar yang berbeda mempunyai hubungan yang positif sebagai pencerminan lancarnya arus informasi pasar. Baffes dan Bruce (2003) juga menyatakan bahwa integrasi pasar akan tercapai jika terdapat informasi pasar yang sama, memadai, disalurkan dengan cepat ke pasar lain dan memiliki hubungan yang positif antara harganya di pasar yang berbeda. Tanda tersebut secara normatif telah sesuai dimana jika terjadi perubahan (peningkatan/penurunan) harga konsumen bawang merah sebesar $1 \%$ akan direspon positif dengan perubahan (peningkatan/pengurangan) harga bawang merah di tingkat produsen sebesar 0,449884\%. Meskipun memiliki tanda yang positif, pengaruh harga bawang merah di tingkat konsumen tersebut bersifat inelastis, dimana perubahan yang besar yang terjadi di pasar konsumen tidak selalu diterima oleh produsen bawang merah dengan besaran yang sama. Hal ini menunjukkan bahwa informasi harga bawang merah di pasar produsen tidak selalu tertransmisikan dengan sempurna ke pasar produsen bawang 
merah. Kondisi tersebut mengindikasikan bahwa adanya gap informasi antara produsen dan konsumen. Gap informasi tersebut dapat disebabkan oleh adanya informasi yang tidak sempurna. Simatupang (1999) menyatakan bahwa perubahan harga suatu barang sering dimanfaatkan para pedagang untuk memanipulasi informasi harga di tingkat produsen sehingga transmisi harga dari pasar konsumen ke produsen cenderung bersifat asimetris dalam pengertian jika terjadi kenaikan harga di tingkat konsumen maka kenaikan harga tersebut tidak diteruskan secara cepat dan sempurna ke tingkat produsen, begitu pula sebaliknya.

Tabel 7. Kointegrasi Jangka Pendek antar Pasar Bawang Merah tingkat produsen dan konsumen

\begin{tabular}{|c|c|c|}
\hline $\begin{array}{c}\text { Error Correc- } \\
\text { tion: }\end{array}$ & D(P_Kons) & D(P_Prod) \\
\hline CointEq1 & -0.046659 & -0.013472 \\
\hline & $(0.02873)$ & $(0.00729)$ \\
\hline & {$[-1.62389]$} & {$[-2.84736]^{* *}$} \\
\hline D(P_Kons(-1)) & 0.493314 & 0.103489 \\
\hline & $(0.16253)$ & $(0.04125)$ \\
\hline & {$[3.03514]^{* * *}$} & {$[2.50862]^{* *}$} \\
\hline D(P_Kons(-2)) & -0.538845 & -0.098625 \\
\hline & $(0.16414)$ & $(0.04166)$ \\
\hline & {$[-1.28277]$} & {$[-1.36727]$} \\
\hline D(P_Prod(-1)) & 0.275679 & -0.126243 \\
\hline & $(0.67549)$ & $(0.17145)$ \\
\hline & {$[0.40811]$} & {$[-0.73633]$} \\
\hline D(P_Prod(-2)) & 0.243516 & 0.050501 \\
\hline & $(0.67549)$ & $(0.17145)$ \\
\hline & {$[0.36050]$} & {$[0.29456]$} \\
\hline C & 64.04388 & 88.19585 \\
\hline & $(236.493)$ & $(60.0250)$ \\
\hline & {$[0.27081]$} & {$[1.46932]$} \\
\hline Sumber: data diolah & & \\
\hline & & \\
\hline & &
\end{tabular}

Setelah diketahui nilai kointegrasi jangka panjangnya, berikutnya adalah menganalisis output VECM yang berupa vektor koreksi kesalahan (error correction term/ ECT). Nilai ECT menunjukkan kecepatan penyesuaian dari keseimbangan jangka pen- dek menuju kepada keseimbangan jangka panjang. Hasil estimasi ECT dan output jangka pendek untuk model integrasi pasar konsumen ddan pasar produsen dapat dilihat pada Tabel 7.

Tabel 7 di atas menunjukkan bahwa hanya pasar produsen bawang merah yang memiliki koreksi kesalahan (ECT) yang signifikan pada taraf 5\% sedangkan untuk pasar konsumen bawang merah tidak memiliki nilai koreksi kesalahan (ECT) yang berpengaruh signifikan. Nilai ECT yang dimiliki oleh pasar produsen bawang merah adalah sebesar $-0,01$. Artinya terdapat penyesuaian dari persamaan jangka pendek menuju jangka panjang sebesar -0.01 atau setiap bulan kesalahan dikoreksi sebesar -0,01 menuju keseimbangan jangka panjang. Tabel 7 juga menunjukkan hasil kointegrasi jangka pendek yang mengindikasikan perubahan harga bawang merah di tingkat produsen dalam jangka pendek dipengaruhi secara nyata pada taraf $5 \%$ oleh harga bawang merah di tingkat konsumen pada satu bulan sebelumnya (lag 2). Harga bawang merah ditingkat produsen pada satu bulan sebelumnya memiliki pengaruh sebesar 0,103 . Angka tersebut mengindikasikan bahwa setiap kenaikan harga konsumen bawang merah pada satu bulan sebelumnya sebesar $1 \%$ akan meningkatkan harga produsen bawang merah pada periode sekarang sebesar $0,103 \%$. Hal ini menunjukkan bahwa dalam jangka pendek, pembentukan harga produsen bawang merah dipengaruhi oleh harga bawang merah ditingkat konsumen atau pembentukan harga produsen bawang merah dalam jangka pendek mengacu pada perubahan harga bawang merah di tingkat konsumen.

Harga bawang merah ditingkat konsumen dalam jangka pendek dipengaruhi harga harga konsumen pada bulan sebelumnya. Harga bawang merah di tingkat konsumen pada bulan sebelumnya memberikan pengaruh 0,49 terhadap perubahan harga bawang merah periode sekarang. Angka tersebut menunjukkan bahwa jika terjadi kenaikan harga bawang merah tingkat konsumen pada bulan sebelumnya sebesar 1\% akan menyebabkan peningkatan harga bawang merah di tingkat konsumen sebesar $0,49 \%$ pada periode sekarang. Angka tersebut mengindikasikan bahwa pembentukan harga bawang merah di tingkat konsumen mengacu terhadap perubahan harga konsumen bawang merah pada periode sebelumnya. Hal ini juga menunjukkan bahwa trend harga bawang merah di tingkat kon- 
sumen akan terus mengalami peningkatan setiap periodenya jika dilihat dalam jangka pendek.

\section{KESIMPULAN DAN REKOMENDASI}

Berdasarkan hasil analisis integrasi pasar bawang merah di Indonesia, harga di tingkat produsen dengan harga di tingkat konsumen memiliki kecenderungan yang sama, namun harga di tingkat konsumen memiliki fluktuasi yang tinggi sedangkan harga di tingkat produsen relatif stabil. Fluktuasi harga bawang merah di tingkat konsumen menyebabkan margin pemasaran yang dihasilkan juga relatif sangat tinggi. Hasil uji kausalitas granger menunjukkan hanya pasar konsumen yang mempengaruhi pasar produsen bawang merah (satu arah). Hal ini terjadi karena produsen bawang merah hanya bertindak sebagai price taker yang hanya tidak memiliki kemampuan mempengaruhi harga. Pasar konsumen merupakan pasar acuan yang menentukan perubahan harga di pasar pengikut (pasar produsen bawang merah). Untuk mengatasi fluktuasi harga yang tinggi di tingkat konsumen diperlukan suatu kebijakan harga tertinggi (ceilling price) untuk mencegah permainan harga oleh pedagang sehingga konsumen tidak dirugikan. Selain itu, untuk meningkatkan posisi tawar petani bawang merah, petani perlu untuk berkelompok agar memiliki posisi tawar yang kuat dalam pemasaran bawang merah serta petani perlu mencari informasi harga melalui media infromasi seperti internet sebelum agar harga yang diterima petani dapat meningkatkan pendapatan petani. Selain itu, diperlukan inovasi pasca panen bawang merah untuk mengatasi terjadinya kelebihan penawaran bawang merah pada saat panen raya.

Hasil estimasi VECM menunjukkan bahwa dalam jangka panjang dan jangka pendek, harga konsumen memiliki pengaruh positif terhadap perubahan harga produsen bawang merah. Tanda tersebut secara normatif telah sesuai dimana jika terjadi perubahan (peningkatan/ penurunan) harga konsumen bawang merah akan direspon positif dengan perubahan (peningkatan/pengurangan) harga bawang merah di tingkat produsen. Meskipun memiliki tanda yang positif, pengaruh harga bawang merah di tingkat konsumen tersebut bersifat inelastis, dimana perubahan yang besar yang terjadi di pasar konsumen tidak selalu diterima oleh produsen bawang merah dengan besaran yang sama. Hal ini menunjukkan bahwa informasi harga bawang merah di pasar produsen tidak selalu ditransmisikan dengan sempurna ke pasar produsen bawang merah. Kondisi tersebut mengindikasikan bahwa adanya gap informasi antara produsen dan konsumen. Oleh karena itu, peran aktif petugas pelayanan informasi pasar (PIP) sangat diperlukan untuk menyebarkan informasi harga kepada pelaku pemasaran utamanya petani bawang. Selain itu, petani harus menyadari pentingnya untuk mengakses informasi pasar utamanya perubahan harga bawang merah.

\section{DAFTAR PUSTAKA}

Ajija S, Setianto D, Primanti M. 2011. Cara Cerdas Menguasai Eviews. Jakarta (ID): Salemba Empat.

Asmara, Rosihan dan Ardhiani, Ruri. 2010. Integrasi Pasar Dalam Sistem Pemasaran Bawang Merah. Agrise 10 (3): 164176.

Asmarantaka, R.W. 2009. Pemasaran Produk-produk Pertanian. Bunga Rampai Agribisnis: Seri Pemasaran. IPB Press, Bogor.

Baffes J and Bruce G. 2003.The Transmission of World Commodity Prices to Domestic Markets Under Policy Reforms in Developing Countries. Journal of Economic Policy Return6(3): 159-180.

Dhewi TS. 2008. Analisis efisiensi bawang merah di Kabupaten Probolinggo. JAkunt Manaj Bisnis Sektor Publik, 4(3): 342-351.

Enders, Walter. (1995). Applied Econometric Time Series. New York: John Wiley \& Sons.

Engle, Robert F. and Clive W.J. Granger (1987), "Co-integration and error correction: representation, estimation, and testing”, Econometrica. Vol. 55, pp. 251276.

FAO, IFAD, IMF, et al. 2011. Price Volatility in Food and Agricultural Markets: Policy Responses. Interagency Report to The G20 on Food Price Volatility.

Firdaus, M. (2011). Aplikasi Ekonometrika untuk Data Panel dan Time Series. Bogor: IPB Press.

Irawan, Bambang. 2007. Fluktuasi Harga, 
Transmisi Harga dan Marjin Pemasaran Sayuran dan Buah. Analisis Kebijakan Pertanian Vol 5 (4): 358 - 373.

Pusat Data dan Informasi Kementerian Pertanian. 2016. Analisis Kinerja Perdagangan Bawang Merah. Jakarta: Pusat Data dan Informasi Kementerian Pertanian.

Ravalion, M. 1986. Testing Market Integration. American Journal of Agricultural Economics 88 (1): 102 - 109.

Rosadi, Dedi. (2012).Ekonometrika dan Analisis Runtun Waktu Terapan dengan Eviews. Yogyakarta: Penerbit Andi Yogyakarta.

Ruslan, J.A. 2016. Transmisi Harga dan Perilaku Pasar Bawang Merah. Tesis. Bogor: Institut Pertanian Bogor.

Simatupang, Pantjar. 1999. Industrialisasi Pertanian Sebagai Strategi Agribisnis dan Pembangunan Pertanian. Pusat Penelitan Sosial Ekonomi Pertanian, Bogor.

Tim Pemantauan dan Pengendalian Inflasi [TPI]. 2013. Laporan pelaksanaan tugas tahun 2013. Jakarta (ID): Kementerian Keuangan.

Widarjono A. 2012. Ekonometrika Pengantar dan Aplikasinya. Yogyakarta (ID): Ekonisia. 